Meta

Journal des traducteurs

Translators' Journal

\title{
A Proactive Approach to the Translation of Bible Stories for Children
}

\section{Luna Beard et Jaqueline S. du Toit}

Volume 50, numéro 4, décembre 2005

Pour une traductologie proactive - Actes

For a Proactive Translatology - Proceedings

Por una traductología proactiva - Actas

URI : https://id.erudit.org/iderudit/019830ar

DOI : https://doi.org/10.7202/019830ar

Aller au sommaire du numéro

Éditeur(s)

Les Presses de l'Université de Montréal

ISSN

0026-0452 (imprimé)

1492-1421 (numérique)

Découvrir la revue

Citer cet article

Beard, L. \& du Toit, J. S. (2005). A Proactive Approach to the Translation of Bible Stories for Children. Meta, 50(4). https://doi.org/10.7202/019830ar

\section{Résumé de l'article}

Cet essai traite de la poésie cognitive comme facilitateur dans les traductions des histoires bibliques pour enfants dans l'environnement multiculturel et polyglotte de l'Afrique du Sud. Les traductions des textes des livres illustrés font généralement correspondre les mots avec des images. Dans l'exemple utilisé, soit la Genèse 28, le rêve de Jacob, dans son texte original en hébreu, est comparé à diverses traductions sud-africaines. La littérature religieuse a été choisie comme sujet de cet essai, étant donné la présence probable de traductions comparables dans la plupart des onze langues officielles de l'Afrique du Sud, mais cet article se limite à la comparaison des traductions anglaise et afrikaans seulement. L'analyse est faite dans le cadre relativement récent de la poésie cognitive, qui applique des approches linguistiques psychologique et cognitive à l'étude de la littérature. La concentration se fait sur la contribution de la linguistique cognitive dans la traduction de la littérature pour enfants dans un esprit de traduction proactive. 


\title{
A Proactive Approach to the Translation of Bible Stories for Children
}

\author{
LUNA BEARD \\ University of the Free State, Bloemfontein, South Africa \\ beardl.hum@mail.uovs.ac.za \\ JAQUELINE S. DU TOIT \\ University of the Free State, Bloemfontein, South Africa \\ dutoitsj.hum@mail.uovs.ac.za
}

\begin{abstract}
RÉSUMÉ
Cet essai traite de la poésie cognitive comme facilitateur dans les traductions des histoires bibliques pour enfants dans l'environnement multiculturel et polyglotte de l'Afrique du Sud. Les traductions des textes des livres illustrés font généralement correspondre les mots avec des images. Dans l'exemple utilisé, soit la Genèse 28, le rêve de Jacob, dans son texte original en hébreu, est comparé à diverses traductions sud-africaines. La littérature religieuse a été choisie comme sujet de cet essai, étant donné la présence probable de traductions comparables dans la plupart des onze langues officielles de l'Afrique du Sud, mais cet article se limite à la comparaison des traductions anglaise et afrikaans seulement. L'analyse est faite dans le cadre relativement récent de la poésie cognitive, qui applique des approches linguistiques psychologique et cognitive à l'étude de la littérature. La concentration se fait sur la contribution de la linguistique cognitive dans la traduction de la littérature pour enfants dans un esprit de traduction proactive.
\end{abstract}

\begin{abstract}
This paper presents cognitive poetics as an agent in overcoming difficulties in translating bible stories for young children in the multi-lingual and multi-cultural South African environment. The translated picture book texts typically involve the integration of words with pictures. For the purposes of this article, the Genesis 28 narrative of Jacob's dream in the Hebrew source text is compared in various South African translations. Religious literature was chosen as subject matter because of the relative certainty of comparative translations in most of the eleven official languages of South Africa, but the present article is limited mainly to English and Afrikaans translations. The analysis is done within the fairly new framework of cognitive poetics, which combines psychological and cognitive linguistic approaches to the study of literature. The focus is on the contribution of cognitive linguistics to the translation of children's literature, in the spirit of proactive translatology.
\end{abstract}

\section{MOTS-CLÉS/KEYWORDS}

cognitive poetics, cognitive linguistics, South Africa, Bible, children's literature

\section{Introduction}

The translation of bible stories for children, otherwise known as "children's bibles" (as opposed to, but not always excluding, bible storybooks [Bottigheimer 1996: 3-13]), inextricably integrate words and pictures in the conveyance of meaning. This article considers techniques that may be used to translate children's bibles by utilising cognitive poetics as framework. It is maintained throughout that the translation of text and the translation of image are to be considered an integral cognitive unit in the transfer of message and meaning to the child. Image and translated text may therefore be used indiscriminately and collectively in the establishment of meaning ${ }^{2}$. The Genesis 28:10-22 account ${ }^{3}$ of Jacob's dream acts as illustration for the relevance of this approach, as it may 
be applied specifically to a South African context ${ }^{4}$. Religious literature was chosen as subject matter because of the relative certainty of comparative translations in most of the eleven official languages of South Africa. And also because of the curious integration of the bible, despite its colonial and missionary past, into the current perception of African indigenous knowledge ${ }^{5}$, a unique and interesting twist in the domestication of bible translation in Africa ${ }^{6}$.

The Constitution of the Republic of South Africa (1996) recognises eleven official languages and grants special privileges to languages used for religious purposes ${ }^{7}$. Despite the constitutionally recognised status of all eleven official languages, the position of at least nine (with the exception of English and Afrikaans) is tenuous at best as far as publication in these languages, either as medium of translation or for original work, are concerned (Fredericks \& Mvunelo 2003) ${ }^{8}$.

Afrikaans and English children's bibles are therefore used almost exclusively in this paper to illustrate a point that will be extrapolated at a later stage in the project to the (hitherto) limited number of other South African translations of children's bibles. The reason being that Afrikaans is the only official South African language, other than English, that is relatively well represented in children's literature at present. Also, where the target audience of the English translation is often indeterminate, an Afrikaans translation is for obvious reasons tailored towards a very specific South African context. It is hoped that our work will clearly indicate the dire need for translations into and from the other nine official languages irrespective of the subject matter or genre, in order to bring all eleven languages to equal status.

\section{Cognitive Poetics}

In the spirit of proactive translatology, this article emphasises Ritta Oittinen's call (2003: 3) for greater emphasis on children's literature in the study of translation. It also highlights a proactive approach to the study of children's literature: a cognitive poetics framework that we suggest may be successfully utilised in studying the translation of children's literature.

The popular attraction the bible holds for both the religious and non-religious may be explained to some extent by the remarkable literary character of the texts (Nida 2003:81), but also by its imbeddedness in Western tradition. This ingrained Western interpretative tradition, does however prove in many respects problematic when translating these texts for an African audience, although the underlying oral nature of the transmission history of the source text, does seem to appeal strongly to a society where orality still holds definite sway in the authoritative transmission of information. In this respect the target culture is much closer to the source culture than the intervening transmission culture would allow.

Bible stories are both rich in fantasy and myth, while generally carrying the added attribute of non-fiction for the religious reader/narrator of these texts. These stories thus embrace the traditional divide between fiction and non-fiction. Furthermore, the stories are typically interpreted by means of an intermediary, i.e. in this instance, read aloud to small children at a specific time, usually just before bedtime. As such several developmental and other concerns contribute to their presentation and understanding, including the oral (pre)history (Dollerup 2003: 83-84) of the source text. A very accommodating framework is therefore needed to address these peculiarities and cognitive poetics provides this: a way of thinking about literature, involving the application of cognitive linguistics and psychology to literary texts. In this it is related to literary criticism where the focus of attention oscillates between 'author-text-reader' (Stockwell 2002: 5) with different approaches placing more or less emphasis on each of the three nodes. Stockwell (2002: 5) points out that cognitive poetics can therefore be successfully superimposed onto this scheme, in the sense that it is not restricted to one or the other. Concerned with literary reading, and with both a psychological and linguistic dimension, cognitive poetics offers a means of accommodating interpretation whether it is an authorly version of the world or a readerly account, and thus allows the possibility of devising how these interpretations are made manifest in textuality (Stockwell 2002:5).

The foundations of cognitive poetics are most directly to be found in cognitive linguistics and cognitive psychology, both in turn forming a large part of cognitive science. It is, therefore not surprising that context, cognition, emotion and felt experience are emphasized in cognitive poetics 
(Stockwell 2002:175). Of these, cognition deserves further attention in the context of this discussion.

Cognition, in this context, refers to how the small child acquires information about the world, how she represents and transforms such information as knowledge, and how she stores, retrieves and uses that knowledge to direct her behaviour. It may therefore be defined as the processes and products of our minds. Examples of cognitive processes are paying attention, perceiving, remembering, thinking, reasoning, planning, solving problems, imagining, inferring, conceptualising, classifying, associating, relating, symbolising, dreaming, and fantasizing. The products of our mind can take on many forms such as writing a book, solving a mathematical problem, creating a painting or inventing something. Cognitive development is the unfolding and also the refinement of these cognitive processes and products (Louw, Van Ede \& Louw 1998:10). Based on research in neurology and cognitive psychology, cognitive linguists assume therefore that there is a continuum between language and cognition (especially body-based cognition, but also cognition acquired on the basis of social and cultural experience) (Barcelona 2000:2). It is particularly this interplay between body-based cognition and cognition acquired on the basis of social and cultural experience that we endeavour to explore in the translations of bible stories for children.

As the formation of religious awareness and the inculcation of religious belief in early childhood are important in this context, the cognitive processes herein involved are also considered. Over the past few decades several new theories about the formation of religious awareness in children have been postulated (see, for example, Hanekom 2000:26-29). In keeping with our cognitive poetics approach, this includes the incorporation of psychology, sociology, anthropology and other disciplines in the understanding of religious belief and belief systems. A holistic approach that accounts for all the human senses, as well as cognitive, conative and emotive aspects, and also complements passive learning processes with activities. The result has been that the exclusive consideration of verbal communication in the transfer of religious knowledge to children is no longer tenable. A viewpoint that takes practical application a step further emphasizes the stimulation of the imagination in the conceptualisation of issues of religion. Finally, as far as the religious potential of the child is concerned, it is now believed that children can experience religious belief at a very early age and before cognitive development is concluded.

Cognitive poetics therefore offers a means of understanding issues of literary value, status and meaning, as they relate to text and context, circumstances and uses, knowledge and beliefs as Stockwell (2002:4) has indicated.

\section{Methodology and Aims}

The nature of our analysis is such that we incorporate major features from cognitive linguistics into our study of children's bibles. The cognitive linguistic concepts are related to the literary context in order to produce a cognitive poetic emphasis. Our aim is to blend key issues of literary reading (such as tone, character, narrative, plot and genre) with the cognitive model that best incorporates the feature. To illustrate this, the story of Jacob's dream (Genesis 28:10-22), is used, and, in particular, matters related to vertical and horizontal space.

\section{The Story of Jacob's Dream}

Jacob, grandson of the patriarch, Abraham, fleeing from his brother Esau, went to sleep at sunset and took a stone as pillow. During the night, he dreams of a ladder/staircase stretching from the earth to heaven with angels moving up and down on it. God appears over or on Jacob during the dream and confirms his relationship with the Jacob. Whereupon Jacob wakes up afraid and realizes that not only is the place where he slept sacred (a "house of God"), but it is a "gate of heaven".

\subsection{Dreams and Imagination}

Imagination is at the core of cognitive poetics. One of the challenges of this approach is therefore to be able to explore its workings and understand its mysterious processes (Stockwell 2002: 173). 
Imagination, or more technically, the ability to project concepts onto other concepts, is a major, albeit general cognitive ability. It is therefore no surprise that cognitive scientists are so interested in imaginative devices such as metaphor (Lakoff \& Johnson 1999).

\subsection{Cognitive Linguistic Tools}

In our approach certain cognitive linguistic tools proved particularly helpful in exploring imagination. Research in cognitive linguistics and more specifically, in cognitive grammar, focuses on two things in particular: space and time. Space is highly structured within this framework. Height, verticality, orientation, direction of movement, prepositions, deictic elements and demonstratives become some of the significant issues addressed within this theoretical framework. For our project, these aspects need to be noted in the Hebrew source text, in translated texts and in pictorial representations/translations.

For the purposes of this study it should also be kept in mind that within cognitive linguistics all linguistic expressions are to a certain extent context-dependent. These cognitive entities, or domains, may be mental experiences, representational spaces, concepts, or conceptual complexes. Our sensory capacities provide a variety of basic domains: the visual system defines the potential for two- and three-dimensional visual sensations, co-ordinated with a multidimensional colour domain. The visual and spatial domains cannot be fully assimilated (even ignoring colour), despite their close association, since a blind person is also perfectly capable of grasping spatial relations (Langacker 1987: 147).

To the extent that ordering and distance can be specified in a coherent, systematic way for certain concepts in a domain, we can describe this domain in terms of one or more dimensions. Time, pitch and temperature exemplify one-dimensional basic domains, since a single, consistent ordering can be determined for the entities that occupy them. We are capable of dealing with space in either two or three-dimensional terms. Psychophysical research has shown that the colour domain is resolvable into the three dimensions of brightness, hue and saturation. Dimensionality is equally important for abstract domains. Several dimensions figure, for instance, in the conception of a network of kinship relations: one is the "vertical" dimension of ascending/descending generations; another is the "horizontal" dimension of lateral relationships; in addition, each node in a kinship network is potentially specified for gender and other properties (Langacker 1987:149). This will all feature in the discussion of the space imagery employed in Genesis 28.

\subsection{Imagery}

"Beloved by children and painters, extravagantly allegorised throughout the history of biblical interpretation ... and an inspiration to hymn writers, the evocative image of Jacob's ladder is mentioned only once in the Bible," (Ryken, Wilhoit \& Longman 1998: 433).

The image of Jacob's ladder, or stairwell (Hebrew: sullām) ${ }^{9}$, has been interpreted innumerably in visionary and mystical ways (Ryken, Wilhoit \& Longman 1998: 433). In the dream, earthly reality opened up into a vision of God and heaven. Jacob's stairwell therefore becomes an image of the holy or numinous, as the narrative hints when it tells us that Jacob, "[...] was afraid (Hebrew: wayîra'), and said, 'How awesome is this place! This is none other than the house of God, and this is the gate of heaven" "(Gen 28:17 RSV).

The imagery of ascent names the movement from a lower to a higher place, and it accordingly partakes of the generally positive associations of being high. Some of the imagery of ascent takes its place within the two-tiered picture of the universe that the bible assumes (Ryken, Wilhoit \& Longman 1998: 49). Heaven is above the earth, and creatures or people (for example, Enoch, Elijah) who move from earth to heaven do so by ascending. Thus angels descend from and ascend to heaven in Genesis 28:12. This agrees with the general ancient Near Eastern context of the source text, where the cultic places for sacrificial purposes as a rule were also referred to as "high places" (Hebrew: bāmôt ). Pilgrimages to Jerusalem, that most sacred of cities in the source text, follow the same directional orientation of "going up" (Hebrew: "âlâ) and for the geographically flat terrain of the Mesopotamian hinterland, the Babylonians and Assyrians compensated with the erection of 
artificial high places, the ziggurats, of which the most famous is the so-called Tower of Babel, polemically alluded to in Genesis $11: 1-9$ to which the Genesis 28 narrative bears strong parallels ${ }^{10}$.

In sharp contrast, the imagery of physical descent, of going down, is part of the directional imagery of the bible that is often close to the surface as we read. The human imagination has, however, nearly always used directional imagery for symbolic meaning as well. A leading cluster of biblical images (Ryken, Wilhoit \& Longman 1998: 204) is based on the general premise of the human imagination that up is good and down bad (as is also captured by conceptual metaphors in cognitive linguistics); namely, that high is desirable and low undesirable; that to ascend is positive and to descend negative.

One of the images of descent in the bible is more positive, though, based on the premise of a two-tiered universe in which God and his heavenly abode are above the earth: God's coming down to earth becomes an image of the intervention of a transcendent deity in the activities of humankind, vis-à-vis the apathy towards the fate of humankind displayed by the gods in other ancient Near Eastern religious contexts ${ }^{11}$. Descent accompanies Yahweh's appearance to his people, whether directly and/or through the agency of angels (Hebrew: mal'äkîm, meaning, literally, "messengers"), but also signifies the deity's active interest in humankind. The dream is therefore a very comforting event, yet it is filled with awe, wonder, and "fear", according to the source text. In this it responds well to what Frey \& Griffith (1987: ix) describe as the typical inconsistency to be found in children's literature: "We see in children's books much of the grotesqueness, metamorphosis, seeming illogic, and teasingly veiled insights that we associate with dreams. To us, great writing for children often tends to hover over the glowing border between good dream and nightmare, between cosy domesticity and sharp family struggle, between edenic nostalgia and sobering maturity."

\subsection{Psychological-Developmental Concerns}

The story of Jacob's dream set at the beginning of the narrative describing Jacob's journey from home (often headlined in children's bibles by the heading, "Running away from home"), provides a learning opportunity for a young child in a religious environment. It provides an adult narrator the opportunity to explain the cultural life world of the source text because of the richness of the pictorial imagery, for example, aspects such as dreams and parental blessings in the ancient Near Eastern world, the nature and role of angels and places of worship, as well as the deity's proximity and protection.

An approach that takes context so seriously, though, has to take cognisance of the many factors that needs to be considered as to the inclusion, graphic presentation and translation of this story in children's bibles.

As regards children's notion of movement along vertical structures, children are usually able to climb stairs as of thirteen months (Louw, Van Ede \& Louw 1998: 168). Children are also aware of social hierarchies from a very young age (Louw, Gerdes \& Meyer 1985: 235). This is important as the Genesis 28:10-22 account has been imbedded in the Jacob Cycle, and directly preceded by the genealogical sequence of verses 6-9. The Jacob Cycle explains the position of Jacob in the tradition as patriarch and Genesis 28:10-22 is pivotal in this account as it acts as confirmation of Jacob's position in the patriarchal hierarchy, as the place where the dream is said to occur, Bethel, is associated with Abraham.

The children's bibles and source material used for the purposes of this study are aimed at children aged 5-8 years. The period from approximately the sixth to the twelfth year of life is known as middle childhood. Psychologists agree that, although it is a period of relative calm in respect of physical development, it is nevertheless an important period in children's cognitive, social, emotional, and self-concept development (Louw, Van Ede \& Louw 1998: 322), thus gaining a better understanding of their world.

At this age balance and elegance of physical movement also improve considerably (Louw, Van Ede \& Louw 1998: 325). They are extremely physical and run, jump, swim and climb up and down frames and structures in free play (Blom 2004:125). 
In terms of reading development, the members of middle childhood fall into the second of Retief's (1990:36) four stages:

$0-5$ yrs: Preschool reader (picture books)

6 - 8 yrs: Beginner reader (picture books)

$9-11$ yrs: Transition away from picture books

12+ yrs: Juvenile literature

There is significant language development during middle childhood. This not only involves an increased vocabulary and more complex sentence structures, but also the improved ability to adapt language and style of language to the context in which it is used. For instance, the child's language while speaking to her teacher will differ from the language she uses when speaking to a friend. Also, between the ages of three and four, preschool children begin to understand figurative expressions such as, "the clouds look like castles". By school going age (roughly at the beginning of middle childhood), children understand metaphorical language such as, "the sun is like a piece of glowing coal" and, "a heart of gold" (Mussen, Conger, Kagan \& Huston 1990).

As for dreaming, Roffwarg, Muzio and Dement (1966) found that neonates spend about half of their sleeping time in REM (rapid eye movement) sleep, associated with dreaming. And the processing of dreams has been done during gestalt play therapy with children as young as six years of age (Blom 2004: 165). This often helps children to develop new strategies for coping with emotions such as fear and anger. This type of therapy is used to great effect for children grieving (losing a loved one to AIDS, for example) and traumatised children (for instance, in cases of rape, abandonment, physical violence, extreme poverty, etc.) in the South African context ${ }^{12}$.

Some of the most important symptoms (Blom 2004:214) that may be experienced by such children include nightmares, fear of strangers, changes in their eating and sleeping patterns, extraordinary fear of the dark, fear of separation or of being alone ${ }^{13}$. Papalia \& Olds (1979: 302) explain the development of new fears in toddlers as follows: "They know so much more now, and one of the things they know is that there are a lot of things to be afraid of. Then, too, their imaginations go wild, and they are worried about being attacked by a lion, being in the dark, being abandoned, or falling from high places."

\subsection{The Text in the Hebrew Bible}

Eugene Nida (2003:76) has pointed out that instead of simply lecturing about principles of correspondence between the source text and the target text, the translation process is far better served by a scholar conferring with a prospective translator, by going through the text together as a means of discovering and anticipating potential problems for the prospective translation. In fact, he says, this is one of the most important procedures, because a problem recognized and accurately identified, is already half solved. This anticipation of difficulties in translating is particularly useful as a translator is thereby prepared for potential hiccups that may arise in the text and can prepare accordingly. As a result the translating process usually proceeds more rapidly and with fewer problems. Nida's suggestion is easily extrapolated to accommodate the present authors' approach to translating children's bibles: taking cognisance of the cognitive life world of both the source and target cultures, as well as the necessary interplay of both text and picture in the translation activity.

South African children's bibles are most often translated from American and British English translations, with little to no cognisance given to cultural specificity in the South African target culture. The American or British children's bible is in turn usually derivative from an "adult" English translation of the Hebrew source text. Nevertheless, it was found that, in most instances, the English "adult" text pretends to the position of source text, thereby ignoring the Hebrew/Aramaic or Greek source text.

As children's bibles lean heavily on images as necessary partners in the conveyance of message, we suggest that translators of children's bibles pay closer attention to the source texts, with the assistance of translators, for the selection of stories, the translation of text and the translation of image. To illustrate our strong emphasis on illustration as part and parcel of 
translation, we refer to three concepts in the Genesis 28 account: the angels, the ladder/stairwell and the position of God.

\subsubsection{Angels}

The prevalence of angels in the Hebrew (Old Testament) source narrative increases with time and their presence and multiplicity in function seems to increase accordingly in the later apocalyptic literature. The Genesis 28 account is however a fairly ancient story imbedded into more recent material and angels seem to function here purely as background imagery ${ }^{14}$, emphasising the extraordinariness of the vertical interchange between the deity (above) and the sleeping human (below). This is however seldom adhered to in the pictorial and textual representations of this story, where much is made of the ladder/stairwell and its occupants darting up and down. The verticality of the interchange tends also to be downplayed in presentations such as Van der Watt \& Joubert's (2002) My eerste boodskap, indicating a horizontal, rather than the source text's firm up-down, hierarchical relationship between the two participants, with the resultant negation of the cognitive imagery attached, as discussed previously.

As far as appearance is concerned, angels in the earlier biblical material are nondescript agents of the deity. In the later biblical material, however, the keen developing interest in the heavenly abode is often associated with elaborate physical descriptions of the angels in terms of light, fire, shining metals, or precious stones, (in accordance with, for example, the book of Ezekiel), and garbed in white linen (according to the book of Daniel) (Newsom 1992: 252).

In depicting these heavenly beings, translator of text and image is therefore often reliant on the post-exilic developing interest in angels in the source culture and the accompanying strong blend of Assyrian-Babylonian iconographic influences that gave rise to it. A possible iconographic derivative for many of the winged images of angels provided in text and illustration is the Assyrian apkallus, primeval (male, adult) "sages" that combined human physicality with the addition of wings (Green 1995: 1848-1849). Many of the traditional children's bibles also depict the angels with wings and illuminated against a bright yellow background. Sometimes the accoutrements of later tradition such as harps and trumpets are added, the figures are androgenous and often also tend towards younger, often childlike, Western features (e.g., Hartman 1995: 22), downplaying the sense of awe and fear evoked by the Hebrew text, in favour of a more egalitarian approach between child-audience and biblical character.

\subsubsection{The Ladder/Stairwell}

As mentioned already, the Hebrew word sullām (stairwell) occurs only once in the biblical text, resulting in many translation variants both in text and image. The stair-imagery in the dream is most probably a derivative from a geographic circumstance in ancient Mesopotamia, where the general absence of high places (often associated with access to the gods/heaven) led to the building of tower-like structures (ziggurats), artificial mountains, for the purpose of worship. These ziggurats are archaeologically well attested throughout the floodplains of the Tigris and the Euphrates rivers. They were multiple tiered tower-like structures that were accessed by enormous ceremonial staircases, of these the greatest was the ziggurat built for Marduk of Babylon (the legendary Tower of Babel). It was 91,5 m in breadth, length and height (Von Soden 1994: 192). The monumental staircases of these towers are the most obvious templates for the vehicle of vertical movement of the angels in the dream.

Some comment has already been made on the origins, and translation, of the vertical motif of the stairwell on which the angels ascend and descend in the Genesis 28 account. It is evident that the lack of obvious functionality of the angels (cf. Sarna 1989:198) in the account has not escaped many of the modern translators of the story. In a clear attempt at simplification (often erroneously associated with adapting adult source material for children), Larsen (1995: 120), for example, completely deleted the angel/stairwell imagery from both text and illustration as superfluous. The passage entitled, "Jacob's Dream", therefore indicates Jacob as a very small boy, sleeping, with an 
empty puff of smoke (a la the comic strips), above his head. The text echoes the "emptiness" left by the absence of the vertical motif: "When Jacob fell asleep he had a dream. God told him everything was going to be alright, ..." (Larsen 1995: 120). The audience is left with a sense of horizontal continuation in narrative and image, thus depriving the reader of any imaginary component, as so eloquently provided by the mix of myth and fantasy in the original account. An even more explicit negation of the vertical imagery is found where the stairs are indicated, but running more or less horizontally across the picture frame (ONS GROOT PRENTEBYBEL 2000: n.p.).

\subsubsection{The Position of the Deity}

The lack of a vertical relationship mentioned in Larsen's (1995: 120) rendering, also contributes to the establishment of a horizontal, rather than hierarchical relationship between the two parties involved: God and Jacob. Matters such as Jacob's "fear", after the event, therefore has to be left untranslated as a result, as it cannot be explained without a sense of the overpowering awesomeness of a deity coming down from heaven to concern himself with the affairs of humanity. It therefore affects the relational depiction of the space between God and humanity and makes it difficult for the child to understand the reason for Jacob's "fear" which Larsen (1995: 89) has to convert into a fear for the uncertainties that the future might hold, rather than a fear of God, as no relational depiction of God vis-à-vis Jacob is given in the rendering of the story.

Also, as mentioned before, in the Hebrew source text the position of God is in no way related to the stairwell and the activities of the angels ${ }^{15}$. God is positioned in relation to Jacob: "above" or "on" or "on top of" Jacob (Hebrew: "al), thereby indicating the authority in the relationship between the two entities in their spatial interaction.

\subsection{The Text and Pictures in the Afrikaans Translated Versions}

Van der Watt \& Joubert (2002) in yet another attempt to draw the $21^{\text {st }}$ century child between the ages of five and eight into the story depicts a rather young Jacob peacefully asleep with his dog by his side. Ryken et al. (1998: 29) points out that the bible invokes the image of the dog quite often, but rarely in a positive light. The Israelites were familiar with dogs, not as cherished pets, but as members of packs that fed at the town dump and roamed the streets at night howling (Psalm 59:6). The struggle for survival at the town dump and a semi-wild existence did not produce friendly dogs. Dogs seemed to know nothing of obedience and were dangerous to pet (Proverbs 26:17). The fear of being eaten by such dogs was real (Psalm 22:16-17).

What is more problematic about this picture is the very rare representation of God, in human guise, on the stairwell. The text emphasizes a verse (Genesis 28:13) from the 1983-translation of the Afrikaans bible, which states that God came and stood by Jacob and spoke to him. (In the Old Afrikaans Version, as is the case for the King James Version, God is indicated as standing at the very top of the ladder.) Nevertheless, the Hebrew source text refers to God's position as "on" or "on top of" Jacob and not necessarily relational in position to the stairwell. And as has been pointed out, this is hierarchically significant in terms of positioning of sacred versus profane; but also in terms of authority, God is by virtue of position, superior to Jacob.

The tone expressed through this picture does not fit the awe and respect ("fear") expressed in the text, as the picture is typically overshadowed by conceptual diminutives: God is small and caricaturised, the ladder (not stairs) is short, the emotionless Jacob is very young (Jacob was at least middle aged), with a small dog by his side.

The conceptual diminutives are often underscored in older Afrikaans children's bibles by a natural tendency in Afrikaans to fill speech and text aimed at children with the diminutive form, for example, "little angels" (Afrikaans: engeltjies), and so forth (see, De Vries \& Geldenhuys n.d.: 36). But in older texts the deity is authority figure is upheld by not applying the same diminutive status to God in either illustration or text. Thereby expressing the power relationship between God and Jacob in terms of big (important) vs. small (less important), rather than as high vs. low, as is the case in the source text. 


\section{Discussion and Future Perspectives}

So far theoretical, linguistic, cognitive poetic and psychological issues have been taken into account. The next step in the research project involves investigating the reception of the various texts on South African children from the designated language communities. This article is therefore but an indicator of the applicability of the cognitive poetics approach to the specific requirements of the multi-lingual and multi-cultural demands of the South African circumstances. And, given the particular challenges posed by eleven official languages, children's literature in translation has received very little attention to date. In this we would like to take the approach of the teacher of philosophy at a university in Ecuador (Nida 2003: 82) who, when speaking of the missionaries, said, "These fine people have learned our language but never our hearts, because they are so unaware of our literature."

\section{Conclusion}

To conclude, as was mentioned earlier, dreams and imagination are central to cognitive studies and the story of Jacob's ladder acts as foil to indicate the interpretative possibilities provided by a cognitive poetics approach to children's bible translation. Text and graphics are inextricably linked to become a cohesive whole and both therefore have equal impact on the understanding of source and target culture and the conveying of message.

This approach presents literature and literary analysis as based in general cognitive experience, including general processes of understanding language. It thus also enables the analyst to make the most of connections with other art forms and media. Hence an ideal frame of reference for the study of picture books for children in multi-lingual and multi-cultural settings.

\section{NOTES}

1. Great inconsistency exists as to whether children's bibles are written by "authors" or "translators", or in fact, "retellers" in the way Beckett (2003) uses the term for the transmission of a tale such as Little Red Riding Hood. We are of the opinion that as children's bibles are based on a Hebrew, Aramaic or Greek source text, the epithet "translator" is more appropriate. Certain elements, such as the selection of stories included (highly problematic given the canonical nature of the source text and the religious basis thereof) and the assignation of subtitles for individual stories, are inevitably the work of modern editors and authors, not always indicated as such in the introduction (where introductions do exist). Furthermore, many children's bibles are dependent on an English or Dutch (for South African audiences) translation of the source text. This translation, most often the King James Version or the Living Bible, Good News Bible, and so forth, often acts in the guise of the Hebrew/Aramaic and Greek source text (a pretender source text, if you will), with no recognition thereof in the children's bibles. Cognisance also has to be taken of translational traditions (Dollerup 2003: 91) the constraints of which are compounded by the confessional and canonical aspects of the source material and the traditional notions of the adult mediator of the text. Ideology is therefore always present in the translation of children's bibles, but often disguised in a traditional lip service to literal reading of religious canon.

2. This may seem self-evident to the translators and scholars pre-occupied with children's literature, but it is an often overlooked aspect of the religious source material on which children's bibles are based. As Othmar Keel (1992: 358) explains: "Although innumeral biblical handbooks are illustrated with pictures from ANE [ancient Near Eastern] sources, and each year sees the appearance of yet another volume of its kind, the relationship between biblical texts and pictures contemporaneous to them remains neglected, in that it has never been studied in a systematically thought-out way, as is normal in the other disciplines of biblical research.” Although what Keel refers to is an iconographical tradition in the transmission of the biblical text, this is as true for children's bibles, if not more so, as the genre as such as been sadly neglected until Bottigheimer started working on this in the 1980s.

3. The account forms part of the larger Jacob cycle (Genesis 25:19 to 35:29), but scholars have long agreed that this story probably predates much of the rest of the cycle and was inserted into it. 
4. This article is imbedded in a six-year research project by the authors. The project is interdisciplinary in nature and combines the collaborators' respective expertise in cognitive linguistics and bible, to focus on Bible interpretation in children's literature. The transfer and interpretation of bible (religious) knowledge from diverse institutional and parental sources to children: visual and literary interplay. The project is funded by the generous financial assistance of the South African National Research Foundation's Thuthuka Program. Any opinion, findings and conclusions or recommendations expressed in this material are those of the authors and therefore the NRF does not accept any liability in regard thereto. The financial assistance of the University of the Free State is also acknowledged.

5. Mogomme Masoga (2004: 141-142) on the bible as part of indigenous knowledge in South Africa: "[...] the biblical text stands in a central position. [...] It is used daily in a variety of contexts - it is used on trains by preachers; it is used to divine and heal by abathandazeli (spiritual/faith healers); it is used [...] and read at many night vigils, by independent and indigenous church preachers and their followers, in cold tents and shanty buildings, [...] characterised by singing, clapping of hands and pulsating drumming, dancing in cycles and humming the songs with a strong sense of African repertoire."

6. A non-traditional application of the term "domestication", but nevertheless, we would argue, applicable in this instance.

7. Article 6(1): "The official languages of the Republic are Sepedi, Sesotho, Setswana, siSwati, Tshivenda, Xitsonga, Afrikaans, English, isiNdebele, isiXhosa and isiZulu." Article 6(5) continues to grant the Pan South African Language Board the authority to promote the development and use of Khoi, Nama and San languages, as well as sign language. It also provides special privilege ("respect") for languages used for religious purposes such as Hebrew.

8. Beard \& Du Toit are at present in the process of conducting a survey on the publication status of children's bibles in all eleven official languages.

9. To complicate matters, this is an example of a hapax legomenon, one of 3000 words that occur only once in the biblical Hebrew corpus.

10. The parallels are well reflected in a number of visual images in picture books, where the direction and form of the staircase often strongly recalls what we know from archaeology of the Babylonian ziggurat referred to in Genesis 11 (cf., for example, Lingo 2003: 22 and Barnes 2001: 29). This parallel reflects the textual references to "gate of heaven", and the like, that tie these two unusual accounts together.

11. The Mesopotamian flood narrative, the Epic of Atrakhasis (first half of the second millennium BCE), provides the prototypical example of the apparent indifference of the ancient Near Eastern deities vis-à-vis humankind. And the flood narrative in Genesis and the Hebrew deity's close involvement with humanity in this narrative is often

considered to be a polemic against the ancient Near Eastern understanding of the divine as disinterested and unaffected by the trials of humanity.

12. It is predicted that as many as a quarter of South African children may be orphaned by the AIDS epidemic in the next five years.

13. Larsen's My bedtime bible (1995) takes cognisance of this by reorganising the selection of bible tales thematically into 365 "devotions for children". On Genesis 28, she asks the child audience (Larsen 1995: 89), "What makes you afraid? How do you think Jacob felt after God talked to him?"

14. Nahum Sarna (1989: 198): "It should be noted, though, that in Jacob's dream, the sullam [staircase], whatever it be, does not function as a channel of communication between man and God." And the angels on the staircase are not active participants in the interaction between the two either.

15. By contrast, God is often depicted, in children's bibles, in relation to the stairs/ladder. In children's bibles God, or a luminous symbolic image depicting the deity, stands at the top of the ladder. In this, the children's bibles follow the text of the King James Version (KJV), a popular pretender-source text: "And he dreamed, and behold a ladder set up on the earth, and the top of it reached to heaven: and behold the angels of God ascending and descending on it. And, behold, the Lord stood above it, [...]" (Gen 28:12-13a KJV). This rendering disagrees from the Hebrew source text.

\section{RÉFÉRENCES}

BARCelona, A. (2000): Metaphor and Metonymy at the Crossroads: a Cognitive Perspective, Berlin, Mouton de Gruyter. 
BARNES, T. (2001): The Kingfisher Children's bible, London, Kingfisher.

BeCKetT, S. L. (2003): “When Modern Little Red Riding Hoods Cross Borders... or Don't...”, Meta 48-1/2, p. 1530.

BLOM, R. (2004): Handbook of Gestalt Therapy. Practical Guidelines for Child Therapists, Bloemfontein, Druforma.

BotTIGHeIMER, R. B. (1996): The Bible for Children: From the Age of Gutenberg to the Present, New Haven, Yale University.

De VRIES, A. \& A. Geldenhuys (n.d.): Die mooiste verhale in die wêreld, Cape Town.

DOLleRUP, C. (2003): "Translation for Reading Aloud", Meta 48-1/2, p. 81-103.

FredericKs, G. H. \& Z. MvUnElo (2003): "Publication of Books in Indigenous South African Languages and their Availability and Use in Public Libraries", South African Journal of Library and Information Science 69-2, p. 133-139.

FREY, C. \& J. GRIFFITH (1987): The Literary Heritage of Childhood: an Appraisal of Children's Classics in the Western Tradition, New York, Greenwood.

GREEN, A. (1995): “Ancient Mesopotamian Religious Iconography”, in SASSON, J. (ed.): Civilizations of the Ancient Near East III\&IV, Peabody, Hendrickson, p. 1837-1856.

HANeKoM, B. (2000): Hoe leer ons kinders glo? Praktiese gids vir ouers, onderwysers en predikante, Wellington, Lux Verbi BM.

HARTMAN, B. (2001): The Lion Storyteller Bible, Oxford, Lion.

KeEL, O. (1992): "Iconography and the Bible", in FreEDMAN, D. N. (ed.): The Anchor Bible Dictionary 3 H-J, New York, Doubleday, p. 358-374.

LAKoff, G. (1987): Women, Fire and Dangerous Things: What Categories Reveal About the Mind, Chicago, University of Chicago.

LAKoff, G. \& M. Johnson (1980): Metaphors We Live By, Chicago, University of Chicago.

LAKoff, G. \& M. Johnson (1999): Philosophy in the Flesh: the Embodied Mind and its Challenge to Western

Thought, New York, Basic Books.

LANGACKER, R. W. (1987): Foundations of Cognitive Grammar I, Stanford, Stanford University.

LANGACKER, R. W. (1990): Concept, Image and Symbol: the Cognitive Basis of Grammar, Berlin, Mouton de

Gruyter.

LANGACKER, R. W. (1991): Foundations of Cognitive Grammar II, Stanford, Stanford University.

LEE, D. (2004): Cognitive Linguistics: an Introduction, Oxford, Oxford University.

Levinson, S. C. (2003): Space in Language and Cognition: Explorations in Cognitive Diversity, Cambridge,

Cambridge University.

LiNGO, S. L. (2003): My klein goeienag-bybel, Vereeniging, CUM.

Louw, D. A., L. C. GERDES \& W. F. MeYer (1985): Menslike ontwikkeling, Pretoria, HAUM.

Louw, D. A., D. M. Van Ede \& A. E. Louw, A. Botha (1998): Human Development, $2^{\text {nd }}$ ed., Pretoria, Kagiso

Publishers.

Masoga, M. (2004): "How Indigenous is the Bible? Challenges Facing $21^{\text {st }}$ Century South African Biblical

Scholarship", Journal for Semitics 13-2, p. 139-158.

Mussen, P. H., J. J. Conger, J. Kagan \& A. C. Huston (1990): Child Development and Personality, $7^{\text {th }}$ ed, New York, Harper \& Row.

Newsom, C. A. (1992): “Angels”, in Freedman, D. N. (ed.): The Anchor Bible Dictionary 1 A-C, New York, Doubleday, p. 248-253.

NIDA, E. A. (2003): Fascinated by Languages, Amsterdam, J. Benjamins.

OitTinen, R. (2003): « Présentation », Meta 48-1/2, p. 3.

ONS GROOT PRENTEBYBEL (2000): Wellington, Lux Verbi BM.

Papalia, D. E. \& S. W. OldS (1979): A Child's World, $2^{\text {nd }}$ ed., New York, McGraw-Hill.

Retief, H. J. M. (1990): "Uitgee van kinderboeke", in CoetZeE, H. S. \& H. J. M. Retief (eds.): Kinder- en jeugboeke: referate gelewer tydens die HAUM-Daan Retief Simposium oor kinder- en jeugboeke, Pretoria,

Universiteit van Pretoria, p. 36-42.

Roffwang, H. P., J. N. MuZio \& W. C. Dement (1966): "Ontogenetic Development of the Human Sleep-Dream Cycle", Science 152, p. 604-619.

Ryken, L., J. C. WiLhoit \& T. LONGMAN III (eds.) (1998): Dictionary of Biblical Imagery, Downer's Grove, InterVarsity Press. 
SARna, N. (1989): The JPS Torah Commentary: Genesis, Philadelphia, Jewish Publication Society.

SмITH, C. M. (1982): "Die gebruik van die kinderverhaal as biblioterapeutiese tegniek deur die maatskaplike werker in gesprekke met kinders", Maatskaplike Werk/Social Work 19-3, p. 229-236.

STOCKWEll, P. (2002): Cognitive Poetics: an Introduction, New York, Routledge.

STUTTERHEIM, H. \& S. KROON (1991): "Die gebruik van biblioterapie in maatskaplike werk", Maatskaplike Werk/ Social Work 27-2, p. 180-190.

VAN Der Merwe, M. (1996): "Biblio-play", in Schoeman, J. P. \& M. VAN Der Merwe (eds.): Entering the Child's World: a Play Therapy Approach, Pretoria, Kagiso, p. 108-116.

VAN DER WATT, J. \& S. JOUBERT (2002): My eerste boodskap, Vereeniging, CUM.

VENTER, E. H. (1998): An Assessment Guideline for the Determination of a Child's Emotional Awareness, Unpublished MA-dissertation, Pretoria, University of Pretoria.

VON SODEN, W. (1994): The Ancient Orient: an Introduction to the Study of the Ancient Near East, translation by D. G. Schley, Grand Rapids, William B. Eerdmans. 